\title{
The Functional Approach to Second Language Instruction
}

\author{
Adam Ismail Mohamed Ahmed ${ }^{1, *}$ \\ ${ }^{1}$ Department of English Language, University College, Alqunfudah, Umm Al-Qura University, Kingdom of Saudi \\ Arabia \\ *Correspondence: Department of English Language, University College, Alqunfudah, Umm Al-Qura University, \\ Al-Gunfudah 21912, P.O. Box 1109, Kingdom of Saudi Arabia \\ Tel: 966-542-807-950 E-mail: ali_adam85@hotmail.com
}

Received: December 15, 2012 Accepted: January 13, $2013 \quad$ Online Published: March 14, 2013

doi:10.5430/wjel.v3n1p92

URL: http://dx.doi.org/10.5430/wjel.v3n1p92

\begin{abstract}
This study aims at investigating the effectiveness of the functional approach to second language instruction in acquiring grammatical accuracy. In other words, the second language instruction that is semantically, interactionally (i.e. the meaning-oriented and interaction-oriented instructional techniques) and structurally based (i.e. the rule-oriented instructional techniques) enhances the acquisition of grammatical accuracy more effectively than the structural approach. The reason for such an investigation has resulted from the fact that many instructors of English use the structural and traditional approaches in teaching grammar. The consequence of using such approaches is the decline of English language among university students. Another reason for this investigation is the globalization of all the aspects of today's life which involves second/ foreign language learners to cope with the discourse of modern civilization, so that they can acquire the cross-cultural understanding worldwide through the multimedia and the other communication channels. This step can be achieved by the functional approach to second/ foreign language instruction. To verify the hypothesis, both the qualitative and quantitative research methods have been used to elicit the required data. The subjects of the study were the students majoring in English at the University of Nyala in Sudan. The data which was collected from the subjects, has been analyzed statistically by using a T-test. The results of the investigation have revealed that the functional approach to second language instruction is more effective in acquiring the grammatical accuracy than the structural approach. The study concludes with pedagogical implications and recommendations for the application of the functional approach in second/ foreign language learning/ teaching.
\end{abstract}

Keywords: functional; structural; approach; grammar; competence; accuracy; acquisition; instruction

\section{Introduction}

The functional view of language originated in 1920 from the works of Bronislaw Malinowski, a professor of anthropology at the University of London. His works provide two important concepts to the functional approach: the context of situation as indispensable for understanding language; and the reference to social and emotive functions in communication (Yalden, 1987). Similarly, the Prague school (a group of scholars mostly Czech or Russian, which held regular meetings during the 1920s and 1930s and published the linguistics of Prague) proposes a functional approach to language study. This approach visualizes language as a tool that performs a number of essential functions or tasks in the community, which uses it. The most outstanding among these tasks is the communicative function - serving the needs and wants of the mutual understanding of individual members of the given language community (ibid). The Prague linguists try to apply their functional views in language teaching. These views are also elaborated by Jakobson (1960), who draws a distinction between every day language and poetry in terms of poetic functions and communicative functions. His dichotomy between poetic speech (expressive) and communicative speech (transactional) is criticized because all the language functions overlap in the verbal communication whether in poetry or everyday language.

In Britain, Firth (1957) derives his theory of context of situation from Malinowski (1923). Firth has developed the application of the situation/ contextual theory in descriptive linguistics, which has led to the functional syllabus design. Malinowski and Firth both represent a view of language as context dependent and sociological in orientation as opposed to the view that language is a self-contained system, and psychological in orientation. 
Halliday $(1973 ; 1975 ; 1976 ; 1978)$ has been influenced by both Malinowski and Firth. His account of meaning and context of situation remains the driving force in linguistics. His writings that are more recent have strong sociolinguistic and functional perspective. His works on the development of functions in the communicative language and language functions in society are connected to his formal linguistic theory (known as systemic functional grammar), has led to the development of notional-functional syllabus, and becomes the base for the modern functional approach to language teaching. According to Halliday (1975), language acquisition is seen as the mastery of linguistic functions.

Moreover, the functional approach to language teaching was popularized in the 1970s by the production of the council of Europe's book entitled "The Threshold Level" by Van Ek and Trim (1974). Based on this book, the principles of functional approach to language teaching and syllabus design are set into practice for the first time in the history of language teaching (Germain, 1982). Since then, there have been thousands of works on functional approach to language teaching and syllabus design (e.g. Berns, 1983; Halliday, 1985; Yalden, 1987; Melrose, 1988; Bankson, 1996; Day and Shapson, 2001; Oka, 2004; Joseph, 2009; Olga and Marianna, 2012)

\subsection{Functional Theory}

The late 1960s witnessed a shift in pattern of research on first language from the nativist/ cognitive side into the functional side, which is considered a deeper move into the essence of language (Brown, 1987). This new move has revolutionized research on first language acquisition. In this respect, the communicative function of language is being investigated in all its variability. However, the generative rules that are proposed under the nativistic framework (Chomsky, 1959, 1965) are abstract, formal, explicit, and quite logical. They deal specifically with the forms of language and not with the very deepest level of language where memory, perception, thought, meaning, and emotion are all interdependently organized in the superstructure of the human mind (Bloom, 1970; Slobin, 1973, 1985; Halliday, 1975, 1985). These scholars argue for a functional approach to the study of first language acquisition. According to the above mentioned scholars, the explanation of language development is dependent upon an explanation of the functions of language which are considered a matter of the interaction of the child's perceptual, interpretive, and cognitive development with the linguistic and non-linguistic events in the child's environment. In other words, child language researchers need to formulate the rules of the functions of language and the relationships of the forms of language to those functions (Brown, 1987). In this respect, Halliday (1985: xiii) states:

All languages are organized around two main kinds of meaning, the 'ideational' or reflective, and the 'interpersonal' or active. These components, called 'meta-functions' in the terminology of the present theory, are the manifestations in the linguistic system of the two very general purposes which underlie all uses of language: (i) to understand the environment (ideational), and (ii) to act on the others in it (interpersonal).

Halliday, in the above quotation, states that all languages are dependent on semantic and pragmatic learning which itself is dependent on the cognitive development of a child.

According to the functionalists' view, there are two levels of language development: the functional level, and formal level. On the functional level, the development is paced by the growth of conceptual and communicative capacities, operating in conjunction with innate schemas of cognition. On the formal level, development is paced by the growth of perceptual and information-processing capacities operating in conjunction with innate schemas of grammar (Brown, 1987).

However, in the area of second language acquisition, the works of Givon $(1981,1983,1984,1985)$ are considered the prominent attempts to develop a functional theory of second language acquisition. In his functional-typological theory, Givon claims that syntactic change is driven primarily by psycholinguistic and pragmatic principles relating to speech perception and production in face-to-face interaction. These principles are themselves derived from more basic ones underlying human perception and information processing. Givon's goal is to develop a unified theory of all kinds of language change, including language acquisition (Larsen-Freeman and Long, 1991).

Pedagogically, there are several attempts to study grammar from the functional perspective (e.g. Halliday (1985, 1994); Dik, (1978, 1989); McKay, 1987; Reid, 1991; Downing and Locke, 1992; Ackerman, 1995; Dalrymple, 2001; Bresnan, 2001). Moreover, the area of syllabus design has also witnessed a functional perspective (e.g. Wilkins, 1976; Finocchiaro, 1979; Yalden, 1987; Melrose, 1991).

\subsection{Functional Grammar}

According to Crystal (2003), functional grammar is a linguistic theory that was founded in the $1970 \mathrm{~s}$ as an alternative to the abstract, formalized view of language presented by transformational grammar. Instead, functional grammar relies on a pragmatic view of language as social interaction. (e.g. Dik, 1978; Halliday, 1985; Bresnan, 2001; 
Dalrymple, 2001; Marin, 2011). According to these studies, functional grammar helps in attaining the notion of grammatical accuracy among second/foreign language learners. It is termed systemic-functional grammar and lexical-functional grammar in accordance with those who see language as a system of systems and those who see it as a combination of lexical relations rather than transformations or operations on phrase structure trees as a means of capturing linguistic generations. In this respect, Dalrymple (2001) defines lexical-functional grammar as a linguistic theory, which studies the various aspects of linguistic structure and the relations between them. He states that the traditional lexical-functional grammar analysis focuses on two syntactic structures: constituent structure (C-Structure) which represents words order and phrasal groups, and functional structure (F-Structure) which represents grammatical functions like subject and object. These structures have separate representations, but are related to each other in systematic ways. Recent lexical-functional grammar works (e.g. Bresnan, 2001) include investigations of rhetorical structure, semantic structure, and other linguistic structures, and their relation to C-Structure and F-Structure. These investigations correlate with the view of Olga and Marianna (2012) that the functional approach to the teaching of grammar is a rich resource for making contextualized meaning in a culture- and language- specific way.

However, Crystal (2003) states that functional grammar focuses on the rules which govern verbal interaction which is seen as a form of cooperative activity, and focuses on the rules of syntax, semantics, and phonology which govern the linguistic expressions that are used as instruments of this activity. For example, in functional grammar, a predicate is taken as the basic element of predication. Full predications are formed from nuclear predications by satellites - elements that turn a nuclear predication into a full predication and specify further properties of the nuclear state of affairs expressed in a sentence such as manner, temporal and locative. Syntactic functions (interpreted semantically) and pragmatic functions are then assigned to elements of predication, and expressed in sentences by the use of expression rules, which deal with matters such as case, agreement, order, and intonation.

Similarly, Halliday $(1985 ; 1994)$, in his systemic-functional grammar describes grammar as the interpretation of grammatical patterns in terms of configurations of functions in a clause and relates functional grammar to text analysis. This is because systemic-functional grammar assumes that meaning is directly related to the structure of language, i.e. language structure is derived of meaning.

As a founder of functional grammar, Halliday (1985) is inspired by his teacher Firth; but the former provides a more systemic and comprehensive theory of the structure of language than does Firth. Hence, Halliday's approach is termed systemic-functional grammar. Systemic Grammar is a phrase structure approach, which is concerned with establishing a network of systems of relationships that will account for all the semantically relevant choices in the language as a whole (Crystal, 2003). Its theoretical framework analyses the unit of structure of a particular language. There are primary three levels of language analysis are recognized. Firstly, form, which is concerned with the organization of the substance of language into grammar and lexis; secondly, substance, that is speech or writing; and thirdly, the total situation, which is largely concerned with semantics. In systemic grammar, the grammatical units have hierarchical structure starting with the bigger or larger first as in the following: sentence, clause, phrase/ group, word, and morpheme. This relationship or system is termed rank scale - that a sentence consists of one clause or more; a clause consists of one phrase or more; a phrase consists of one word or more; and a word consists of one morpheme or more. Language as a whole is then characterized as a system (e.g. the linguistic system of English) which contains a hierarchically ordered arrangement of systems. The term system refers to a network of patterned relationships constituting the organization of language. The language system is constituted by the phonological, grammatical, and semantic systems. In Halliday's systemic-functional grammar, the notion of system receives a special status and is made a central explanatory principle; the whole language is being conceived as a system of systems.

\subsection{Functional Literacy and Grammatical Accuracy}

The functional literacy as an area of enquiry recognizes personal and social needs of an individual that should be communicated orally or in written text. The sociolinguistic concept of communicative competence has considerable potential for developing the understanding of functional literacy at the level of the individual (Verhoeven, 1997). The fundamental concept of communicative competence is the ability to produce and understand ideas appropriate to the social context in which they occur, with emphasis on the accuracy of communication process (Pagliano, 1997) and the correction of language form. The rationale for this claim is that the violations in language use (errors) whether they are syntactic, semantic, morphological, or phonological, may break down the communication process between the interlocutors in a given situational context.

Furthermore, the comprehensive definition of grammar as "a description of the speakers' competence" (Fromkin and 
Rodman, 1993: 13) and as unconscious linguistic system which underlies the native speaker's use of language in terms of comprehension and production (White, 2003), supports the essential role of grammatical accuracy in communicative competence. Therefore, Canale and Swain (1980) claim that communicative competence comprises four different competences: grammatical competence, discourse competence, strategic competence, and sociolinguistic competence. Furthermore, Verhoeven (1994) extends the existing framework of communicative competence by adding a fifth level - decoding / coding competence. He presents functional literacy as encompassing:

(1) grammatical competence (which includes phonology, semantics, morphology, and syntax);

(2) discourse competence (in which cohesion and coherence are fundamental);

(3) strategic competence (which involves the planning, execution, and evaluation of writing);

(4) sociolinguistic competence (which entails an understanding of the literacy conventions appropriate to a given society and culture); and

(5) coding/ decoding competence (which is applicable to writing and entails writers to be familiar with writing conventions).

Similarly, Hymes (1974: 75) defines communicative competence as "what a person needs to know in order to communicate effectively in culturally significant situations". According to this quotation, communicative competence is the ability of the native speakers to use language for communication in real situations. In speech community, communication is organized in terms of events, which are termed communicative events, or literacy events, because they refer to activities involving oral or written communication. It is not enough to acquire knowledge of linguistic structure; language learners must also possess the appropriate schemata regarding the culture of the language is being learned in order to understand the communication and be able to respond using the vocabulary and structures that correspond to specific social situation. Hence, there is a growing importance of sociology in language teaching.

Based on the above definitions, accuracy is considered an essential condition of both communicative competence and functional literacy, which are considered identical twins. In this respect, Krashen (1988) claims that in learning second language, there are two distinct ways help the development of language competence. One way of second language competence comes via formal learning of grammatical rules, which is considered a conscious activity. The other one is unconscious ability which enables the learner to acquire the language naturally similar to the way a child acquires his mother tongue without formal learning of grammatical rules and he often depends on the feeling of correctness of his output. In both cases, it is clear that accuracy is an essential condition in second language acquisition. Accuracy is defined by EL Sheikh (2001) as the act of using a language conforming to the standard grammatical rules quite free from errors, whether they are syntactic, semantic, morphological or phonological.

To fulfill these objectives, functional/ functional-notional syllabuses are needed for functional description of language through learning materials that are designed from a social and interactive perspective on language as discourse. This description should show in a consistent way how functional grammar enables speakers and writers to encode their purposeful messages appropriately in text or speech. Placing meaning firmly in the context of grammar is the basic characteristic of the systemic-functional model of grammar, which is provided by Halliday (1985).

\subsection{Rationale of the Study}

The rationale for this study is based on the fact that the English language competence among the Sudanese university students has been declining, especially in the last three decades. Some studies (e.g. Abdalla, 2000) relate this decline to the formal approaches which are used in the teaching of English in Sudan. According to Weaver (1996), the grammar studies have revealed that the formal study of grammar does not lead to a better reading, speaking, writing, or editing. Hence, a functional approach to the teaching of English in Sudan can be proposed. Moreover, there are few studies in the area of the functional approach to the teaching of English in Sudan. Another reason for this investigation is the globalization of all the aspects of today's life which involves second language/ foreign language learners to cope with the discourse of modern civilization, so that they can acquire the cross-cultural understanding worldwide through the multimedia and the other communication channels. This step can be achieved by the functional approach to second language/ foreign language instruction. Therefore, the above mentioned justifications are considered tangible reasons for conducting this investigation. The functional approach to second language/ foreign language instruction is assumed to develop the English language competence of the students. This assumption is based on a number of earlier studies (e.g. Halliday, 1985; Melrose, 1988; Ochola, 2001; North, 2005) that have proved the effectiveness of the functional approach to second language/ foreign language instruction in 
developing the grammatical and Communicative Competence in the learners of a language.

\subsection{Statement of the Problem}

Depending on the notion that "Many linguists understand the term grammar to be limited to questions of the internal structure of sentences..." (McCarthy, 2001:11), many teachers of English use traditional and structural approaches in teaching English grammar. Similarly, most of grammar lessons in the students' textbooks are based on the notions of traditional and structural grammar. Traditional grammar, for instance, assigns words to classes such as noun, verb, etc. This is commonly referred to as parsing or identifying parts of speech. They are defined semantically, e.g. a 'verb' is a word that expresses an action or doing. Such definition makes students confuse the uses and functions of many grammatical items.

Furthermore, grammar teaching in foreign and SL situations focused on presenting learners to the forms without giving attention to the aspects of learning these forms. Such an approach was derived from the structuralist school of grammar, which was led by De Saussure (1959), and was firstly criticized by Firth (1957): "Structuralism emphasizes segmentation and phonemics and excludes meaning" (cited in Beaugrande, 1991: 197). Firth then split up meaning into a series of component functions (ibid). Meaning, thus, becomes a term for the whole complex of functions, which a linguistic form may have. This is the major concern of functional grammar. Based on such concepts, functional grammar is concerned with understanding the ways in which language is used for different purposes and in different situations and how language is structured in such cases (Dik, 1989). For instance, the verb in functional grammar is explained in terms of factuality, probability, focus, tense/ aspect, control, movement, number, and person. In other words, the formal structure of the verb is interrelated with the semantic, functional, and interactional dimensions. Study of grammar in such a way involves looking at the whole text and taking context into account (McCarthy, 2001). Thus, using the functional approach to second language/ foreign language instruction will help students effectively acquire grammatical accuracy.

\subsection{Objectives of the Study}

(1) To investigate the comprehensiveness of the functional theory of language acquisition and the eclecticism of the functional approach to second instruction.

(2) To provide a functional approach to the teaching of the English tenses, which can be generalized to the teaching of other grammatical categories.

(3) To prove that the functional approach to second instruction effectively facilitates the acquisition of grammatical accuracy.

\subsection{Research Questions}

Does the functional approach to second instruction facilitate the acquisition of grammatical accuracy more effectively than the structural approach?

If so, what are the factors that make the functional approach to second instruction more effective in acquiring the grammatical accuracy than the structural approach?

\subsection{Hypothesis of the Study}

This Study is aimed to verify the following hypothesis:

'The functional approach to second instruction has more positive effect on acquiring grammatical accuracy than the structural approach'. In other words, second language instruction that is semantically, interactionally and structurally based, enhances the acquisition of grammatical accuracy.

\subsection{Methodology of the Study}

The hypothesis of this study proposes that the functional approach is more effective in acquiring second language grammatical accuracy than the structural approach. Thus, both the qualitative and quantitative methods have been used to elicit the required data. The subjects of the study were the students who were majoring in English at the University of Nyala in Sudan. They have been divided into two equal groups (the control group and the experimental group). In the treatment period, the control group has been given materials with a structural description of the English tenses; the experimental group has been given materials with a functional description of the English tenses. Both groups have been given a pre-treatment test and a post-treatment test on the English tenses. Then, the scores of both groups have been analyzed statistically by a T-test to identify the significant difference between the means scores of the control and experimental samples. The validity and reliability of the test have been assessed, and a pilot study has been conducted on a group of students of English in the distance learning programme at the University of 
Nyala.

\subsection{Significance of the Study}

This study is aimed at suggesting a functional approach to second instruction, basically in the area of English grammar for university students. Therefore, the outcome of this study will help the course designers to apply this approach in designing grammatical materials that effectively facilitate the acquisition of grammatical accuracy. Furthermore, this study will guide teachers of English in Sudan to rely on one of the recent and modern approaches in the area of second language instruction.

\section{Data Analysis}

The data which was collected from the subjects in this study, was analyzed by a T-test which is considered the most suitable statistical measurement to verify the hypothesis of the study. The data was collected from 180 students who were majoring in English at the University of Nyala in Sudan. They were divided into two groups (control and experimental). Both groups were pre-tested. The control group was given a treatment, which was a structural approach to the teaching of the English tenses. The experimental group was given a treatment, which was a functional approach to the teaching of the English tenses. Two days after the treatment, both groups were post-tested.

Therefore, the analysis of the data will focus on the comparison of the T-test output of the scores of these two groups as a means to justify the hypothesis of the study which proposes that ' the functional approach to SL instruction is more effective in acquiring the grammatical accuracy than the structural approach'. In other words, the functional approach to second language instruction which is semantically, interactionally, and structurally based, is more effective in acquiring the grammatical accuracy than the structural approach. Hence, the structural approach has been used as a comparative variable.

Both table $1(\mathrm{~A} \& \mathrm{~B})$ and table $2(\mathrm{~A} \& \mathrm{~B})$ show the T-test outputs of the pre-test and post-test scores of the sample group which received the structural instruction and the sample group which received the functional instruction. Table 3 (A\&B) shows the T-test output of the post-test scores of the students who received the structural instruction (group A) and the students who received the functional instruction (group B).

Table 1: Pre-test and Post-test Scores of the Students Who Received the Structural Instruction

A.

Paired Samples Statistics

\begin{tabular}{rccccc}
\hline & & Mean & N & Std. Deviation & Std. Error Mean \\
\hline Pair & Pre-test scores & 6.656 & 90.000 & 4.427 & .467 \\
1 & Post-test scores & 7.544 & 90.000 & 4.667 & .492 \\
\hline
\end{tabular}

B.

Paired Samples Test

\begin{tabular}{|c|c|c|c|c|c|c|c|}
\hline & & & Paired Differe & & & & \\
\hline & & Mean & Std. Deviation & Std. Error & $\mathrm{t}$ & df & Sig. (2-tailed) \\
\hline & & & & Mean & & & \\
\hline Pair & Pre-test scores & -.8889 & 1.52466 & .16071 & -5.531 & 89 & .000 \\
\hline 1 & Post-test scores & & & & & & \\
\hline
\end{tabular}

Table 2: Pre-test and Post-test Scores of the Students Who Received the Functional Instruction

A.

Paired Samples Statistics

\begin{tabular}{llcccc}
\hline & & Mean & $\mathrm{N}$ & Std. Deviation & Std. Error Mean \\
\hline Pair & Pre-test scores & 6.856 & 90.000 & 4.916 & .518 \\
1 & Post-test scores & 12.756 & 90.000 & 6.273 & .661 \\
\hline
\end{tabular}


B.

Paired Samples Test

\begin{tabular}{llllrrc}
\hline \multicolumn{5}{c}{ Paired Differences } & & \\
& & Mean & Std. Deviation & t & df & Sig. (2-tailed) \\
\hline Pair & Pre-test scores - & 5.9000 & 4.04483 & -13.838 & 89 & .000 \\
1 & Post-test scores & & & & & \\
\hline
\end{tabular}

Table 3: Post-test Scores of the Students Who Received the Structural Instruction (group A) and the Students Who Received the Functional Instruction (group B)

A.

Paired Samples Statistics

\begin{tabular}{llcccc}
\hline & & Mean & N & Std. Deviation & Std. Error Mean \\
\hline Pair & Structural instruction & 7.578 & 90.000 & 4.589 & .484 \\
1 & Functional Instruction & 12.500 & 90.000 & 6.382 & .673 \\
\hline
\end{tabular}

B.

Paired Samples Test

\begin{tabular}{llccccc}
\hline \multicolumn{5}{c}{ Paired Differences } & & \\
& & Mean & Std.Deviation & t & df & Sig. (2-tailed) \\
\hline Pair & Structural instruction - & -4.9222 & 8.17536 & -5.712 & 89 & .000 \\
1 & Functional Instruction & & & & & \\
\hline
\end{tabular}

As table 1 (A\&B) and graph (1) indicate, there is a significant difference between the means scores of the pre-test and post-test of the sample group which received the structural instruction $(\mathrm{t}=-5.53, \mathrm{p}<.001)$. The mean score of the post-test $($ mean $=7.54$, std. deviation $=4.67)$ is greater than the mean score of the pre-test (mean $=6.66$, std. deviation $=4.43$ ). The difference between the means scores of the pre-test and the post-test is -.89 .

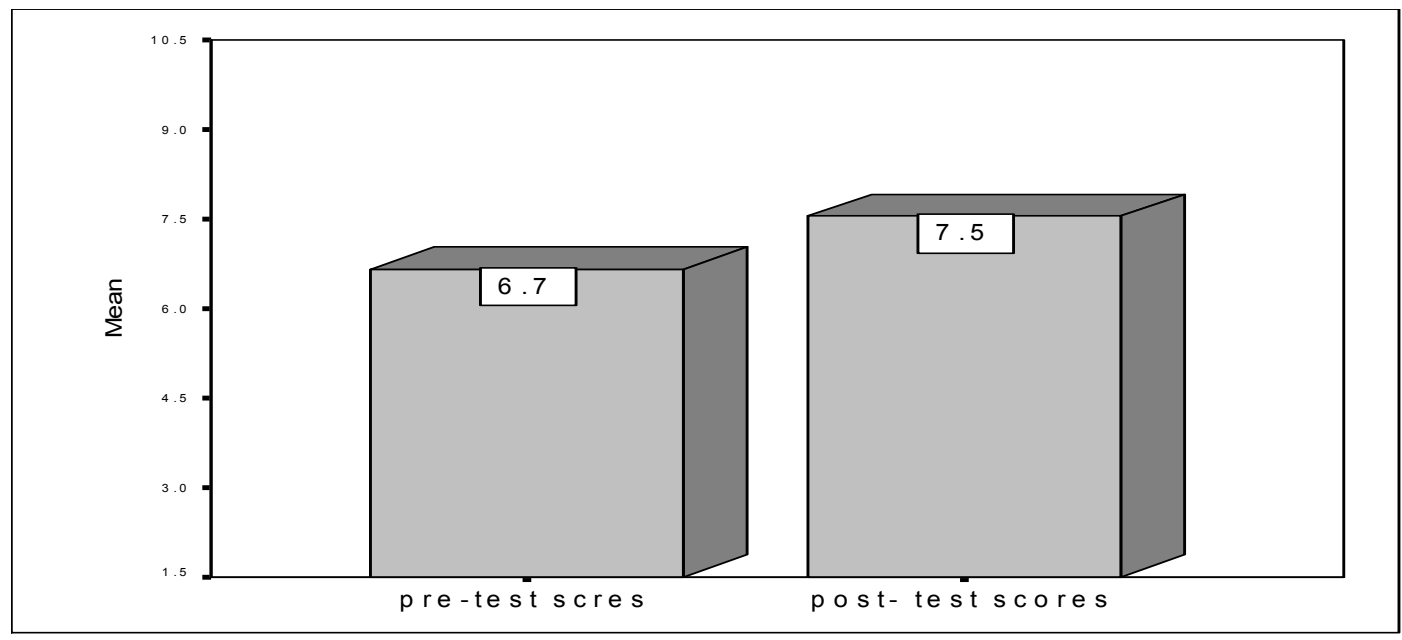

Graph 1: Means of the Pre-test and Post-test Scores of the Students Who Received the Structural Instruction

Table 2 (A\&B) and graph (2) show that there is a significant difference between the means scores of the pre-test and post-test of the sample group which received the functional instruction $(\mathrm{t}=-13.84, \mathrm{p}<.001)$. The mean score of the post-test $($ mean $=12.76$, std. deviation $=6.27)$ is greater than the mean score of the pre-test $($ mean $=6.86$, std. deviation $=4.91$ ). The difference between the means scores of the pre-test and post-test is -5.90 . This difference is greater than the difference between the means scores of the pre-test and post-test of the sample group which received the structural treatment (means difference $=-.89$ ). 


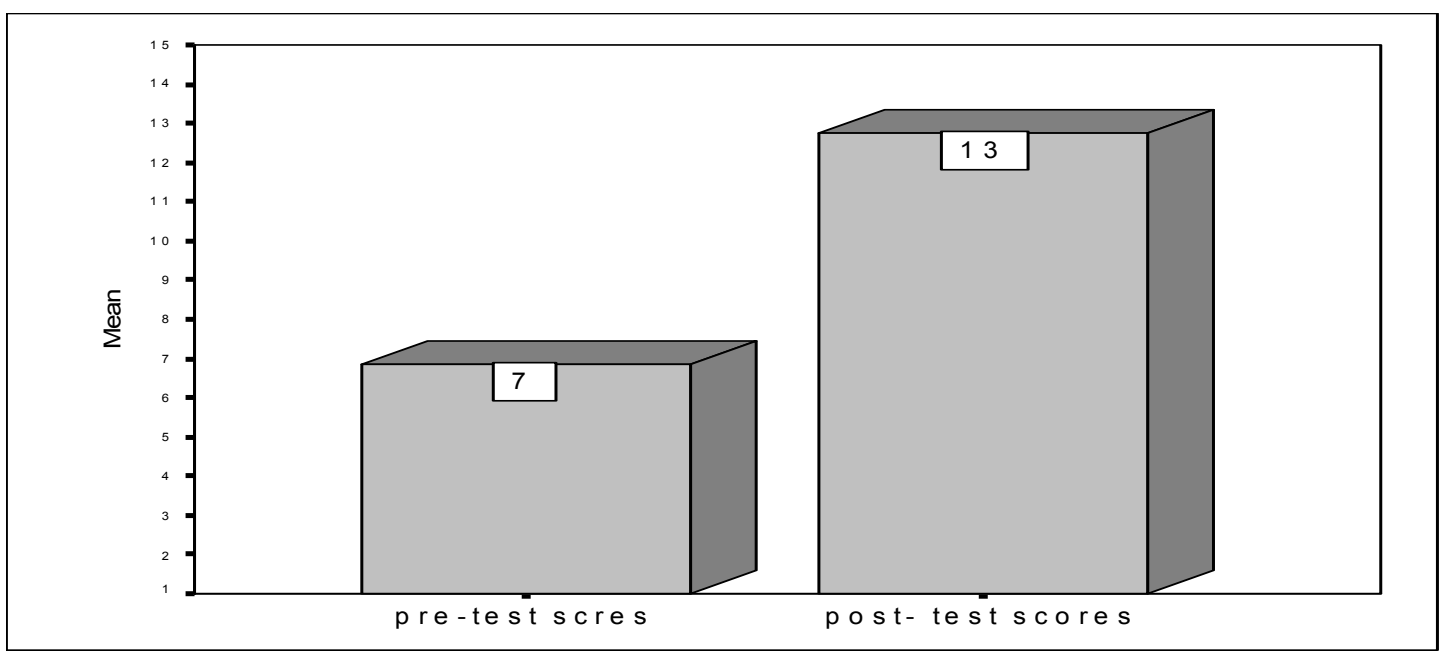

Graph 2: Means of the Pre-test and Post-test Scores of the Students Who Received the Functional Instruction

Table 3 (A\&B) shows the T-test output of the students who received the structural instruction (group A) and the students who received the functional instruction (group B).

As table 3 (A\&B) and graph (3) indicate, there is a significant difference between the means scores of the group which received the functional instruction and the group which received the structural instruction $(t=-5.71, p<.001)$. The mean score of the group $(\mathrm{B})$ which received the functional treatment (mean $=12.50$, std. deviation $=6.38)$ is greater than the mean score of the group $(\mathrm{A})$ which received the structural treatment $($ mean $=7.58$, std deviation $=$ 4.59). The difference between the means scores of the control group (A) and the experimental group (B) is -4.92 .

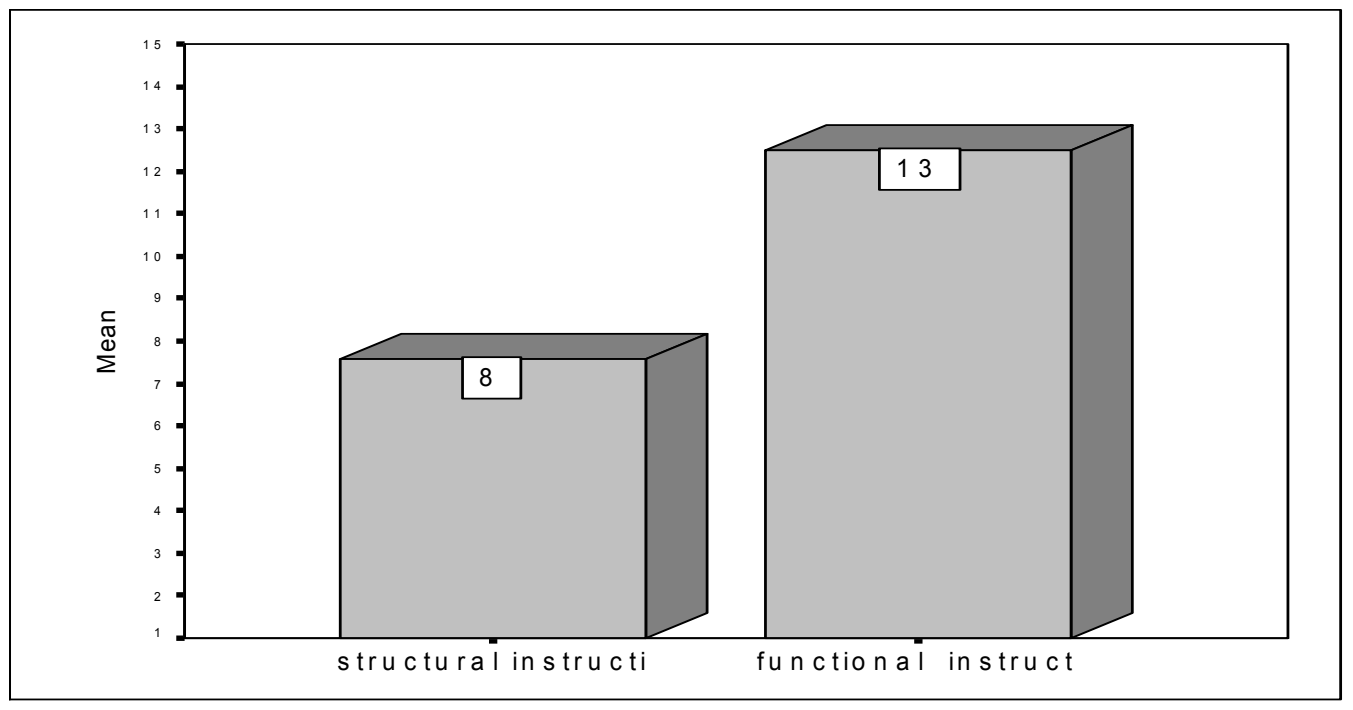

Graph 3: Means of the Post-test Scores of the Students Who Received the Structural Instruction (group A) and the Students Who Received the Functional Instruction (group B)

\subsection{Discussion of the Results}

The results inferred from table 1,2 , and 3 justify that the functional treatment is more effective in acquiring grammatical accuracy than the structural treatment. In other words, these results prove that the hypothesis of the study is factual, i.e. the functional approach to second language teaching which is semantically, interactionally, and structurally based, provides more positive effect on the rate of acquiring grammatical accuracy than any other approach. These results support the research findings of several scholars who investigate the effectiveness of functional approach to second language instruction (e.g. Harley, 1989; Lund, 1997; Day and Shopson, 2001; Mohan and Beckett, 2003; O'Halloran, 2003; and North, 2005; Martin, 2011). The findings of all these studies emphasize 
the superiority of the effectiveness of functional approach in acquiring second language. Therefore, the result of the current study can be generalized to all the grammatical items, i.e. all the grammatical items can be acquired effectively by using functional approach to second language instruction.

However, the results of this study indicate that the majority of English at the University of Nyala lack the knowledge of English tenses. This is mostly due to two reasons. The first is that in their schooling, the students were taught the English tenses through the traditional and structural approaches to second language instruction, which are limited to the study of the internal structure of sentences (McCarthy, 2001). Such approaches do not help in eliminating the process of fossilization (Larsen Freeman and Long, 1991) which is kept in the learner's interlanguage (Kanno, 1998). The Second reason is that the teaching of English tenses at the university level is ignored by most lectures. This is due to the wrong assumption that the students have already been taught English tenses at the secondary school level and have no need to be taught again. Another fact drawn from the results is shown in the lack of the knowledge of English tenses among all students. This result was inferred from the t-test output in table 1 and 2 in which the means scores of the pre-tests of both group are nearly to be equal. The mean score of the pre-test of group (A) which received structural instruction (mean $=6.66)$ and the mean score of the pre-test of group $(\mathrm{B})$ which received functional instruction (mean $=6.86$ ) are considered very low compared with the total mark of the test which is 40 . Generally, these results reflect the lack of knowledge of English tenses due to the use of traditional and structural approaches in teaching; therefore, it can be generalized to all other grammatical aspects.

\subsection{Summary of the Results}

The results of this study have revealed the following:

1) The functional approach to second language instruction is more effective in acquiring the grammatical accuracy than the structural approach.

2) The functional approach to the presentation of the English tenses is more effective than the structural approach for university students learning English.

3) The functional approach may also be used for the teaching of other linguistic aspects (e.g. vocabulary, writing, and discourse analysis).

4) The students' participation and communicative competence are greater in the functional approach than in the structural approach.

5) There is Lack of response and interest in acquiring the English tenses through the structural approach.

6) The study of the functions of a linguistic expression that is structurally, semantically, and pragmatically based, facilitates the process of language acquisition/ language learning.

7) The functional approach trains the students to think for themselves about the structure of the language and develops their analytical skills.

\section{Pedagogical Implications}

A great deal of research has been done in the application of the functional approach to second language instruction (e.g. Cullen, 1996; Lund, 1997; Day and Shapson, 2001, Mohan and Beckett, 2003). The outcome of these studies has centered on a common result that the functional approach to second language instruction has been the most effective approach in helping language learners use the language appropriately during their communicative interactions in a variety of real-world situations which can be utilized for teaching grammar, the four language skills, and discourse analysis. This is in line with the findings of the current study which are considered of great significance for English language instructors at the school and university level in Sudan. According to these studies, the communicative competence of the learners of a language is developed and promoted through the functional approach to second language instruction and course design. The potentiality of the functional approach in developing communicative competence in its broadest sense, is due to the fact that it incorporates form, function, meaning, and the speaker's/ writer's appropriate choice of words in the learning/ teaching process. This is parallel with the findings of Day and Shapson $(1991 ; 2001)$ who found a greater level of grammatical accuracy through the integration of the formal and functional approaches in language teaching. In other words, the study of the functions of a linguistic expression through a structural, semantic, and pragmatic based approach, facilitates the process of language acquisition/ language learning in general and learning or acquisition of the grammatical accuracy in particular.

However, due to the globalization of all the aspects of today's life, learners of a language need to cope with such a 
phenomenon linguistically and culturally. Finocchiaro and Brumfit (1983) state that the major characteristic of the functional approach to second language instruction is the accountability to the individual needs of the students. This means that in order to cope with modern civilization, second language learners need to use a real and appropriate language to communicate with others. The communication can take place face-to-face or through the modern information technology such as mobile phone, internet, chatting on satellite TV, etc. To attain such knowledge, Oka (2004) proposes the implementation of the cultural and functional literacy in second language instruction, which is defined as the knowledge and skill required to function in today's civilization. Therefore, second language learners need to be acquainted with the discourse of the modern civilization that achieves the cross-cultural understanding through the functional approach to language teaching.

Furthermore, many scholars have approached grammar as a comprehensive term that encompasses all the branches of linguistics (e.g. Halliday, 1985; Reid, 1991; Givon, 1990; Dalrymple, 2001; Huang and Morgan, 2003). The works of these scholars are considered a revolt against the formalized view of language, which is presented by the structural and the transformational schools of grammar. Their functional analysis of grammar has shed light on many new grammatical issues that the second language teacher/ learner must be aware of. For example, the clause as a representation, the clause as a message, and the clause as an exchange (Halliday, 1994), or the semantic functions, the syntactic functions, and the pragmatic functions of the clause (Siewierska, 1991).

The functions of the English tenses in a text is another area that both teacher and learner need to be aware of. The study of the functions of the English tenses involves the systematic analysis of the relation between the meanings, the tense forms in a text, and the contextual and pragmatic functions (Gvozdanović and Janssen, 1991). Generally, the functional approach to the study of grammar focuses on how language works to achieve a variety of different functional and communicative purposes. Thus, the functional study of grammar involves the language teachers to base their instruction on situational contexts on which the speakers/ writers make their choices of words.

\section{Recommendations}

In the light of the results of the current study and the results of the reviewed studies, several recommendations can be provided, especially in the area of teaching grammar, the four language skills, vocabulary, and discourse analysis. The main purpose of the recommendations is to draw the attention of the second language teachers and learners to some important issues in the application of the functional approach to second language instruction. Therefore, the recommendations mentioned below are seen as very useful hints in the field of English as second or foreign language:

1) The English language instructors are advised to apply the functional approach in teaching all the linguistic aspects including grammar, the four language skills, vocabulary, and discourse/ text analysis.

2) Due to the comprehensive nature of the functional theory of language acquisition and the eclecticism of the functional approach, teachers of English as second/ foreign language should be aware of the first and second language acquisition research findings that are relevant to the classroom practice, and the ways of applying them. This entails teachers to update themselves with the innovative insights and ideas in the area of teaching English as second/ foreign language.

3) English language teachers should help the learners to acquire and develop a holistic and comprehensive knowledge of the language rather than concentrating on discrete unrelated items of the language.

4) Students' knowledge of the language can be developed through the exploration and analysis of authentic discourse/ text. This entails teachers to advocate learning strategies and teaching techniques that train the students to think for themselves about the structure of the language and develop their analytical skills. This is in line with the view that a discovery approach to grammar is an effective pedagogical option in second language classrooms, and it is one of the basic features of the functional approach to second language instruction.

5) English language teachers should help the students to see grammar as a comprehensive term that incorporates all the branches of linguistics in the process of relating form to meaning, and meaning to situation, which is the main concept of functional grammar.

6) The English language instructors should develop communicative competence in their students. Communicative competence is defined as the ability to produce and understand ideas appropriate to the social context in which they occur, that leads to the accuracy of the communication process which is achieved by the use of accurate structure. 
7) The functional syllabus represents an innovative discovery in the field of English as second/ foreign language during the seventies till now, but unfortunately, most of English language syllabuses in Sudanese schools and universities rely on formal and situational syllabuses. Therefore, Sudanese English language syllabus designers at the school and university levels should incorporate functional approach in their syllabus design.

8) Since the professional training is one of the basic pillars of the teaching process, Sudanese instructors of English should be trained on the application of the functional approach to second language instruction at the school and university levels.

9) Coping with the revolution of the information technology and the wide spread of the application of the computer-assisted language learning, English language instructors should be acquainted with up-to-date applications of the computer-assisted language learning, especially in the area of the functional grammar. Moreover, utilizing the multimedia in second language teaching and learning is a potential process that aids the application of the functional approach in the English language classroom.

10) In line with the functional literacy, which recognizes the personal and social needs of an individual, English language course designers should apply the learner-centered approach which is considered one of the features of the functional approach to second language instruction. The argument for this recommendation is that the learner-centered approach is based on the concept of language acquisition as communicative and interactive functions that fulfill the learner's needs, and that language competence is built through the actual language use.

11) The development of communicative interaction is one of the most important principles of applying the functional approach to second language instruction. Therefore, instructors of English language should base their instruction on the interactive tasks such as role-play, group discussion, information gap, etc.

12) Content-based instruction is considered a potential source for the application of the functional approach to second language instruction, because it yields the contexts that facilitate the interaction between the learner's background knowledge and the target linguistic items. Therefore, Sudanese English language instructors and syllabus designers are advised to apply the content-based approach.

13) The development of motivation is one of the driving forces in second language acquisition/ learning; therefore, language instructors should use eclectic techniques, content-based instruction, situational contexts, task-based instruction, learner-centered approach, and modern technology to develop the learner's motivation.

14) According to the whole language approach and the holistic nature of the functional approach, the four language skills may be taught integratively. Such integration will accelerate the development of fluency and accuracy in the learners.

15) The learners of English as second/ foreign language should be involved in the error correction process which is considered an effective technique for attaining grammatical accuracy. This can be applied by self-correction or peer-correction techniques

\section{References}

Abdalla, S. A. (2000). Investigating Sudanese EFL learners' written discourse competence: the case of the fourth year English students in some national universities. Unpublished Ph.D. Thesis, University of Khartoum, Sudan.

Ackerman, F. (1995). Lexical-Functional Grammar: Handbook of Pragmatics. Amsterdam: North Holland Publishing Co.

Bankson, R. L. (1996). An English for specific purposes curriculum for Japanese businessmen. Unpublished M.A. Thesis, California State University, Domingues Hills, USA.

Beaugrande, R. (1991). Linguistic Theory: The Discourse of Fundamental Works. London: Longman.

Berns, M. S. (1983). Functional approaches to language and language teaching: another look. TESL Talk, 15(2), 44-64.

Bloom, L. (1970). Language Development: Form and Function in Merging Grammars. Cambridge: Mass: MIT Press.

Bresnan, J. (2001). Lexical-Functional Syntax. Oxford: Blackwell Publishers.

Brown, D. (1987). Principles of Language Learning and Teaching (2nd edition). Englewood Cliffs, N.J.: Prentice-Hall. 
Canale, M., \& Swain, M. (1980). Theoretical bases of communicative approaches to second language teaching and testing. Applied Linguistics, 1, 1-47.

Chomsky, N. (1959). A review of B. F. Skinner's verbal Behaviour. Language, 35, 26-58.

.............(1965). Aspects of the Theory of Syntax. Cambridge: MIT Press.

Crystal, D. (2003). A Dictionary of Linguistics and Phonetics (5th edition). Oxford: Blackwell.

Cullen, T. (1996). Schemata and second language acquisition. A paper presented at the annual meeting of the teachers of English to speakers of other languages, Chicago, USA. ERIC Database. Document No. ED394325.

Dalrymple, M. (2001). Lexical-Functional Grammar, Vol. 34 of Syntax and Semantics. New York: Academic Press.

Day, E. M., \& Shapson, S. M. (1991). Integrating formal and functional approaches to language teaching in French immersion: an experimental study. Language Learning, 41(1), 25-58. http://dx.doi.org/10.1111/j.1467-1770.1991.tb00675.x

(2001). Integrating formal and functional approaches to language teaching in French immersion: an experimental study. Language Learning, 51(1), 47-80. http://dx.doi.org/10.1111/j.1467-1770.2001.tb00014.x

De Saussure, F. (1959). Course in General Linguistics. New York: McGraw-Hill.

Dik, S. C. (1978). Functional Grammar. Amsterdam: North Holland Publishing Co.

Dik, S. C. (1989). The Theory of Functional Grammar, Part 1: The Structure of the Clause. Dordrecht: Foris.

Downing, A., \& Locke, P. (1992). A University Course in English Grammar. New York: Prentice Hall International.

El-Sheikh, F. I. (2001). The effect of accuracy on fluency: a case study of graduating students majoring in English language in Omdurman Islamic University. Unpublished M.A. Thesis, Omdurman Islamic University, Sudan.

Finocchiaro, M. (1979). The functional-notional syllabus: promise, problems, practices. English Teaching Forum, 17(2), 11-20.

Finocchiaro, M., \& Brumfit, C. (1983). The Functional-Notional Approach: From Theory to Practice. New York: Oxford University Press.

Firth, J. R. (1957). Papers in Linguistics 1934-1951. Oxford: Oxford University Press.

Fromkin, V., \& Rodman, R. (1993). An Introduction to Language (5th edition). Fort Worth: Harcourt Brace College Publishers.

Germain, C. (1982). The functional approach to language teaching. Modern Language Journal, 66, 49-57.

Givon, T. (1981). Typology and functional domains. Studies in Language, 5, 163-193.

...........(1983). Topic continuity in discourse: an introduction. In T. Givon (Ed.), Topic Continuity in Discourse: A Quantitative Cross-Language Study (pp. 1-42). Amsterdam: John Benjamins.

............(1984). Universals of discourse structure and second language acquisition. In W. Rutherford (Ed.), Language Universals and Second Language Acquisition (pp. 109-136). Amsterdam: John Benjamins.

.........(1985). Function, structure and language acquisition. In D. Slobin (Ed.), The Cross-Linguistic Study of Language Acquisition (pp. 1005-1028). Hillsdale, N.J.: Erlbaum.

.........(1990). Syntax: A Functional-Typological Introduction: Vol. 2. Amsterdam and Philadelphia: John Benjamins.

Gvozdanović, J., \& Janssen, T. (eds.) (1991). The Function of Tense in Texts. Amsterdam: North-Holland Publishing Co.

Halliday, M. A. K. (1973). Explorations in the Functions of Language. London: Edward Arnold.

.........(1975). Learning How to Mean: Explorations in the Development of Language. New York: Arnold.

.(1976). Learning How to Learn. London: Edward Arnold.

(1978). Language as a Social Semiotic. London: Edward Arnold.

(1985). An Introduction to Functional Grammar. London: Edward Arnold.

..(1994). An Introduction to Functional Grammar (2nd edition). London: Edward Arnold.

Harley, B. (1989). Functional grammar in French immersion: a classroom experiment. Applied Linguistics, 10(3), 331-360. 
Huang, J., \& Morgan, G. (2003). A functional approach to evaluating content knowledge and language development in ESL students' science classification texts. International Journal of Applied Linguistics, 13(2), 234-262. http://dx.doi.org/10.1111/1473-4192.00046

Hymes, D. H. (1974). Foundations in Sociolinguistics: An Ethnographic Approach. Philadelphia: University of Pennsylvania Press.

Jakobson, R. (1960). Closing statement: linguistics and poetics. In T. Sebeok (Ed.), Style in Language (pp. 45-61). Cambridge: MIT Press.

Joseph, D. (2009). Rule and Meaning in Teaching Grammar. Language and Linguistics Compass, 3(1), 199-221. http://dx.doi.org/10.1111/j.1749-818X.2008.00119.x

Kanno, K. (1998). Consistency and variation in second language acquisition. Second Language Research, 14, 376-388.

Krashen, S. (1988). Second Language Acquisition and Second Language Learning. London: Prentice Hall International.

Larsen-Freeman, D., \& Long, M. (1991). An Introduction to Second Language Acquisition Research. London: Longman.

Lund, K. (1997). Does everyone learn Danish the same way? A length investigation of adult acquisition of Danish. Unpublished Ph.D. Thesis, Copenhagen University.

Malinowski, B. (1923). The problem of meaning in primitive languages. In C. K. Ogden \& I. A. Richards (Eds.), Meaning of Meaning (pp. 296-336). London: Routledge and Kegan Paul.

Martin, F. (2011). Computational Aspect of Lexical Functional Grammar. Language and Linguistics Compass, 5(1), 1-18. http://dx.doi.org/10.1111/j.1749-818X.2010.00261.x

McCarthy, M. (2001). Issues in Applied Linguistics. Cambridge: Cambridge University Press.

Mckay, S. L. (1987). Teaching Grammar: Form, Function, and Technique. London: Prentice Hall.

Melrose, R. (1988). A systemic-functional approach to communicative course design in English language teaching. Unpublished Ph.D. Thesis, Polytechnic of Wales, United Kingdom.

...........(1991). The Communicative Syllabus: A Systemic-Functional Approach to Language Teaching. London and New York: Printer Publishers.

Mohan, B., \& Beckett, G. H. (2003). A functional approach to research on content-based language learning: recasts in causal explanations. Modern Language Journal, 87(3), 421-432. http://dx.doi.org/10.1111/1540-4781.00199

North, S. (2005). Disciplinary variation in the use of theme in undergraduate essays. Applied Linguistics, 26(3), 431-452.

O'Halloran, K. L. (2003). Systemics 1.0: software for research and teaching systemic functional linguistics. RELC Journal, 34(2), 155-177. http://dx.doi.org/10.1177/003368820303400203

Ochola, E. D. (2001). A socio-pragmatic approach to the use of meta-discourse features in effective non-native and native speaker composition writing. Unpublished Ph.D. Thesis, University of South Carolina, USA.

Oka, H. (2004). A non-native approach to ELT: universal or Asian? Asian EFL Journal, 6(1), 1-10.

Olga, L., \& Marianna, R. (2012). Grammar Dilemma: Teaching Grammar as a Resource for making meaning. The Modern Language Journal, 96(2), 270-289. http://dx.doi.org/10.1111/j.1540-4781.2012.01333_1.x

Pagliano, P. J. (1997). The acquisition of communicative competence amongst children with speech and language impairment. In B. Davies \& D. Corson (Eds.), Encyclopedia of Language and Education, Vol. 3: Oral Discourse and Education (pp. 157-166). The Netherlands: Kluwer Academic Publishers.

Reid, W. (1991). Verb and Noun Number in English: A Functional Explanation. London and New York: Longman.

Siewierska, A. (1991). Functional Grammar. London and New York: Routledge.

Slobin, D. (1973). Cognitive prerequisites for the development of grammar. In C. Ferguson, \& D. Slobin (Eds.), Studies of Child Language Development (pp. 1-19). New York: Holt, Rinehart and Winston.

..(1985). Cross-linguistic evidence for the language-making capacity. In D. I. Slobin (Ed.), The Cross-Linguistic Study of Language Acquisition (pp. 1157-1249), Vol. 2: Theoretical Issues. Hillesdale, NJ: 
Lawrence Erlbaum Associates.

Van Ek, J., \& Trim, A. (1974). The Threshold Level in a European Unit/ Credit System for Modern Language Learning by Adults. Strasbourg: Council of Europe.

Verhoeven, L. (1994). Modeling and promoting functional literacy: theoretical issues and educational implications. In L. Verhoeven (Ed.), Functional Literacy (pp. 3-34). Amsterdam and Philadelphia: John Benjamins.

.........(1997). Functional literacy. In V. Edwards \& D. Corson (Eds.), Encyclopedia of Language and Education, Vol. 2: Literacy (pp. 127-132). The Netherlands: Kluwer Academic Publishers.

Weaver, C. (1996). Teaching grammar in context of writing. English Journal, 85(7), 15-25.

White, L. (2003). Second Language Acquisition and Universal Grammar. Cambridge: Cambridge University Press. Wilkins, D. A. (1976). Notional Syllabuses. Oxford: Oxford University Press.

Yalden, J. (1987). Principles of Course Design for Language Teaching. Cambridge: Cambridge University Press. 